\title{
Clio
}

Women, Gender, History

$37 \mid 2013$

When Medicine Meets Gender

\section{Andropause and menopause: sexuality by prescription}

\section{Véronique Moulinié}

Translator. Regan Kramer

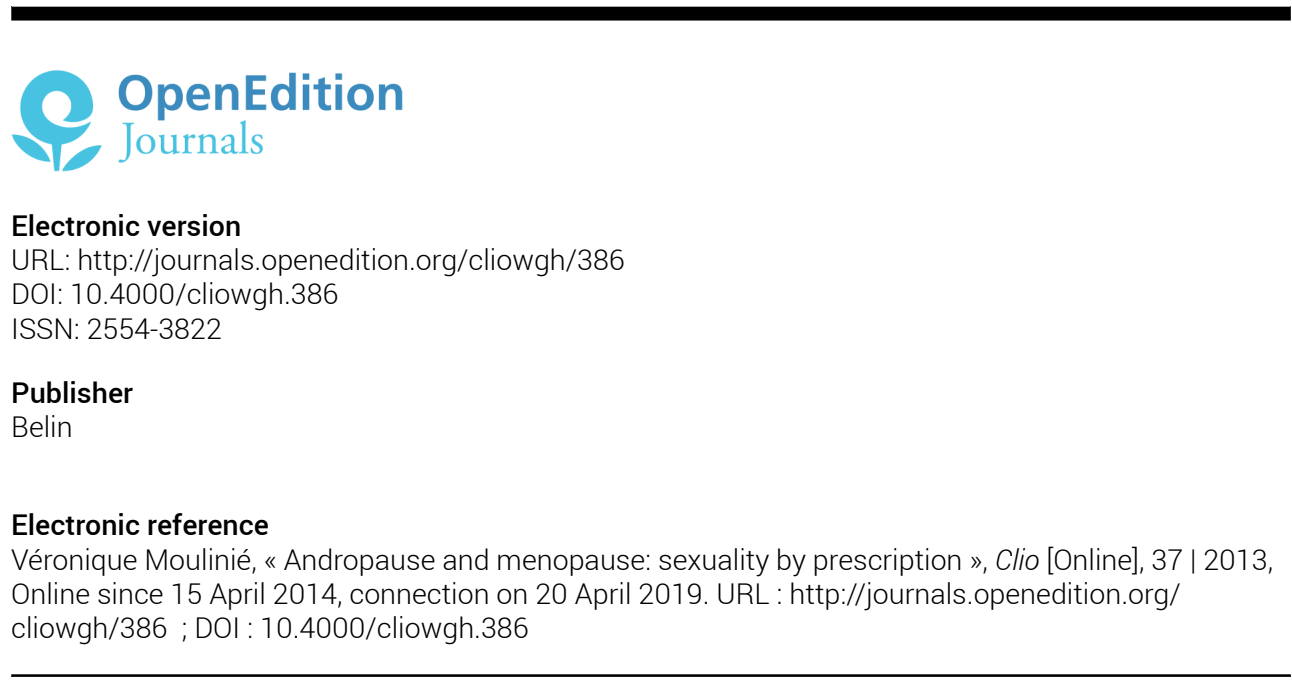

Clio 


\section{Andropause and menopause: sexuality by prescription}

Véronique MOULINIÉ

The thought process that preceded writing these pages brought back the memory of something that happened a long time ago. In the mid1980s, when I was in high school in Saint-Pierre, ${ }^{1}$ a small industrial town in the southwest of France, only a few students took German. While we all acknowledged that Mr. Letourneau was a great teacher, we also thought he was a bit of a weirdo. Very tall and thin, with an emaciated face hidden by dark glasses, he never smiled and always looked serious. We thought of him as someone distant whose mind was filled with dark thoughts; and we loved to speculate about what those thoughts might be. One day, Rémi, who was a little older than the rest of us, thought he'd figured it out. Although I can't remember his exact sentences, a few of the words he pronounced still echo in my mind. Mr. Letourneau had "problems with his wife." He had married an "old lady," who was 10 years older than he and had "been through menopause," and "had it all taken out" recently. So she was "all dried up," and "couldn't do it anymore." Consequently, he had to "keep his pants on" from then on. I remember how uncomfortable the whole little group suddenly felt. It wasn't so much because of the crudeness of Rémi's speech per se, it was because of how doubly incongruous his explanation was. To begin with, the tone was absolutely incongruous. We would have applauded if our classmate had used vocabulary from the science of the psyche that we excelled at in philosophy class, but we weren't ready for - in fact we totally rejected - this bodily medicine, or more like bodily mechanics, that

1 People and place names have been changed. 
he was spreading out so brazenly before our eyes. And then the place where he said it, and the audience he said it to were incongruous as well. We all knew - more or less - what the words "menopause" and "all" meant. We had overheard them in conversations between women like our mothers and grandmothers - who didn't, by the way, necessarily agree about them. But they were still deeply foreign to us, and they didn't belong in a conversation between young near-adults in high school no less!

Yet Rémi wasn't the foulmouthed blackguard we accused him of being. All he was doing was echoing a representation that was widely accepted, at least in that rural region, about how bodily and sexual norms evolve with age. ${ }^{2}$ They imposed abstinence in "the autumn of life," as the somewhat old-fashioned but still common expression goes. ${ }^{3}$ This representation has come into being over the course of the last two centuries, through complex relationships, resulting from reformulations and exchanges between science and common sense, between "old wives' tales" and universities, medical innovation and traditional social practices.

\section{Words and Woes}

For centuries, doctors granted only a few lines to menstruation in general, and to its definitive cessation in particular, as part of broader treatises about female physiology. To the point that there was no medical terminology for the phenomenon. That all changed during the $19^{\text {th }}$ century. The word "menopause" appeared for the first time

2 This reflection constitutes the core of my thesis, which was about such common contemporary surgical operations as tonsillectomies, adenoidectomies, and appendectomies during childhood and adolescence, and hysterectomies and procedures performed on the prostate around the change of age. See Moulinié 1998.

3 It seems to have survived the $20^{\text {th }}$ century without difficulty. In 1932, Dr. Victor Pauchet wrote L'automne de la vie. L'bomme et la femme à l'âge critique, ("The Autumn of Life, Men and Women at a Critical Age") and 80 years later, in March 2011, the European Center for the Study and Teaching of Ethics organized a conference in Strasbourg called: "The Autumn of Life: the Ethical Stakes of Ageing." 
in the 1810s-1820s. ${ }^{4}$ Along with the word, a phase of life was invented, conceived as a turning point in a woman's existence, one that is marked by a cohort of ailments and strange behaviors, which doctors, in a stream of theses, ${ }^{5}$ articles and other publications, described, probed, analyzed and pondered endlessly. And that is the key: "menopause" explicitly became a woman's "disease," which, by definition, needed treatment. In addition, throughout the second half of the $19^{\text {th }}$ century, taking advantage of progress in anesthesia and asepsis, surgery explored women's abdomens, developing first ovariotomies $^{6}$ then hysterectomies. These operations were known about well beyond the operating theatre, as Rémi's comment shows. Men were concerned too. Their turn just came later, you could say. It wasn't until the 1940s that the first research on the "male menopause" was published, although it soon acquired a more specific, serious and scientific-sounding name: andropause. Associated with a disappearance or at least a severe loss of sexual potency that needed to be treated seriously - in all the term's polysemy - it too became a matter for doctors.

Thus throughout the $19^{\text {th }}$ and $20^{\text {th }}$ centuries, the medical establishment gradually took control of the bodies and sexuality of women and men of advancing years. It is time to take a look at how this slow-motion medical coup d'état, if I may be so bold, took place, as well as the circumstances and reasons that made it possible? ${ }^{7}$.

4 The word "ménespausie" was first used by Charles de Gardanne, in his Avis aux femmes qui entrent dans l'âge critique, ("Advice to Women Entering a Critical Age"), published in 1816. Five years later, the word "ménopause" appeared in the title of the second edition of the book. See Tillier 2005 and Delanoë 2001 and 2007.

5 Annick Tillier has come up with 200 of them for the 19 th century alone. See Tillier 2005.

6 For more about the “ovariotomy trend," see Scull \& Favreau 1987.

7 Social sciences, particularly ethnology, have only recently begun to take an interest in menopause and andropause. While research and publications devoted to them were very rare in the 1990s (Delanoë 1997; Héritier-Augé 1998), they are somewhat more frequent now. In Europe, there is, most notably, the work of Virginie Vinel and of Nicoletta Diasio, among others (Diasio 2002; Diasio \& Vinel 2007 and 2010; Vinel 2002, 2004a, 2004b, 2005, 2007, 2008). 


\section{Women's Bodies: Women's Words}

The interviews I performed in the early $1990 \mathrm{~s}^{8}$ brought out an obvious sexual division: women's verbosity about the ailments related to both men's and women's change of life were equaled only by men's silence or irony on the same subject.

The women I spoke to described in great detail the ills that afflicted their bodies from, "a certain age" : night sweats that made sleep difficult, exhausting even the sturdiest constitutions; erratic menstruation that might appear twice in a single month then not at all for weeks on end; "hemorrhaging" that "drained all their blood," which they interpreted as the first symptoms of a "fibroma;" hot flashes that overwhelmed them suddenly, forcing them to remove clothing; mood swings that tossed them from laughter to tears, "without knowing why;" "dark thoughts" that led some of them to "consider the unthinkable;" "nerves on edge" that caused incomprehensible outbursts of anger, upsetting their nearest and dearest. They are sure of one thing though: all of this upheaval, both physical and psychological - not despite but precisely because of how polymorphous it was - was the signature of what the most advanced in age called the "change of life", a term that seemed old-fashioned to the younger ones, often their own daughters, who preferred to talk about "menopause." But they all agreed in the belief that the time had come for them to "get operated on" to "have it all out," as the only way to put a stop to the physiological chaos. By the time they went in for an "appointment," their minds were already made up, their selfdiagnosis already established. Doctors rarely contradicted them, yielding instead without a fuss to their requests for the almighty scalpel. There's nothing surprising about this harmony between women and doctors as to the need for removal. After all, didn't they

8 These interviews took place essentially between 1991 and 1995. They were performed in and around Saint-Pierre, in a rural area, with both men and women who were then aged 50 to 80 , and who belonged to what is called - in a convenient but imprecise term - les classes populaires: factory workers, farmers, shopkeepers and civil servants.

9 It is less the age per se $(47,50,51)$ than events such as the birth of a grandchild, that establish entry into menopause or pre-menopause (Moulinié 1998: 139-143). 
share the same perception of menopause and of the disturbances it necessarily led to?

For the older women I interviewed, the "change of life" was essentially about blood. After having stayed on track - a term that should be understood almost topographically - unimpeded for decades, their blood was going back to the erratic wandering it had been prone to in their childhood and youth, ${ }^{10}$ seeming to be lost inside their bodies, desperately seeking a way out, knocking at the most unexpected spots and causing a host of problems. Still, over decades, the explanations seemed to have aged poorly. Out with the stories about "boiling blood" that "goes to your head" and that's suddenly "darker and thicker than it used to be," which the older women told - with a touch of embarrassment sometimes, as they were all too aware of the condescending smiles their tales elicited. The younger women preferred a more "scientific" dissertation about "male" and "female" hormones whose "levels" were suddenly too high or low, depending - abnormal, in any case. It would be more precise to say that, without abandoning the discourse about blood in the least, they supported it, completed it and justified it by resorting to a hormonal discourse. However, if you didn't get taken in by the medical jargon, which the women often handled with disconcerting ease, you realized that the two types of discourse shared many resemblances. What's more, the women's knowledge was strangely close - in fact, practically identical - to the doctors'. It would be tempting to think that this represented nothing more than a banal phenomenon of transmission or "popularization" of knowledge, which, escaping from medical circles, gradually trickles down, with a slight time lag, into society. Yet it seems to me that the system we are seeing is subtler than that. The women I interviewed drew as much of their knowledge from day-to-day conversations with other women as

10 During childhood and the teenage years, blood seems to wander around the body, looking for a way out, popping up in all sorts of places. So it needs to be channeled, so to speak, and prevented from reaching certain areas (the nose and throat, for example) the better to assign it to its rightful place (the genitals) and keep it there. This explains the success of the minor surgical removals that are performed on young people, such as tonsillectomies, adenoidectomies and appendectomies. See Moulinié 1998: 85-110. 
from medical encyclopedias intended for everyone, articulating with ease the theories of each, as though, rather than being divergent, they created a coherent whole. Indeed, in many ways, you could think that "scholarly" medical knowledge had latched onto the "old wives' tales," wrapped them in theories and covered them with obscure medical jargon, giving them a scientific veneer; then given them back to women, who couldn't help but recognize and appreciate them. Finally, it seemed clear that knowledge was circulating between women and doctors on a closed circuit, each side feeding into the other. What follows will amply confirm that impression.

\section{Men's Bodies: Men's Silence, Women's Words}

While it wasn't hard to get women to talk about women's complaints, getting men to talk about andropause was something else again entirely. ${ }^{11}$ To begin with, the term itself was unfamiliar to them. And those who did know it were snide about it. "That's a load of crap," was the basic message. I wasn't much more successful when, dropping the term that bothered them so much, I tried to get them to discuss the pathologies associated with men and aging. The interviews were deplorably deficient. One could obviously think the fact that I'm a woman contributed to the problem. After all, "talking about women's problems with other women," even if one of them just happens to be an ethnologist with a tape recorder, is more common. It could be seen as a type of female bonding or socializing. But it's clearly trickier for a man to talk openly about the consequences of prostate surgery, or even, though less so, about an attack of gout, suddenly resulting in a painfully swollen toe, to a representative of the "fair sex", who, to make matters worse, wasn't even a doctor! It goes without saying that resorting to jokes, often bawdy ones, was a theoretically efficient conversation-avoidance strategy. It was also a way of playing down worrisome aspects of the issue. Clearly these subjects were not easy to talk about. But my interviewees weren't much chattier when it came to discussing medical issues that were a priori less private, like cholesterol levels or strokes, to name but two. Once again, they didn't have much to say.

11 See Moulinié 2000. 
While they felt these afflictions deep inside them, they were, for the most part, unable to elaborate upon them. So they turned to their wives for help, confiding to them the task of "saying the body". Wives who were never far off, as though they had known from the start that their assistance would soon be required. In a nutshell, the men suffered the ailments in their bodies, leaving to their spouses the task of describing the cause, and of contextualizing their specific case within a more general theory of male physiology.

And what did the wives talk about? Explanations like "rushes of blood," "attacks" that the older ones feared might be the last, and the gout that confined to bed some "bon vivant" husbands who enjoyed the simpler pleasures, like good food and wine, were no longer up to date. They had given way to more technical ones like cerebrovascular accident and "infraction" 12 as well as references to cholesterol and the mysteriously worrisome triglycerides. But you couldn't pull the wool over the women's eyes. They weren't thrown by the somewhat obscure meaning of all that terminology. As far as the women were concerned, all those ailments had to do with blood, its condition and flow. Due to advancing age, their husbands' blood had become both thicker and dirtier and, when all was said and done, as erratic as their own. Their words conjured up an image of male blood subjected to severe turbulence - just like female blood. They made no bones about it, either. "Well, if that's how it is for us, it must be the same for them," "Their blood is acting up on them too, they just don't like to talk about it," or even, "People think only women go through the change of life, but men get it too." Those were the comments dripping with meaning between the lines - that best summed up their point of view.

Yet these learned feminine explanations didn't suit the men at all. Having called on their spouses for help, they then tried to shut them up, with a few well-chosen phrases, intended to prove that they shouldn't be believed: "What are you talking about? That's utter

12 In most conversations, "infarctus", the French medical term for "infarction" or heart attack, became "infractus", probably because the latter - with its proximity to "fracture" or "rupture" of a vein, artery or even the heart - expressed the deeper nature of the problem better. 
nonsense!", "Since when did you go to medical school?", "So what do you know about all that? Huh, you should know, I guess!" But the husbands protested in vain, because not only did the wives ignore their objections, but at the end of the day, even the men themselves wound up recognizing the truth of what the women said. The men had no way out: with no knowledge of their own bodies, they had to let the women proclaim "truths" that they could or would not hear... but for which they had no alternatives to offer. They were cornered! And sick at heart, of course. What was so hard to swallow was that the women's diagnosis went well beyond a few pills or medications. The men knew what was really at stake. The fact was that to explain their husbands' change-of-life ailments, the women drew inspiration from their own bodies, and specifically from the actions of their own blood that had marked out the stages of their lives: from its appearance at puberty that was the first step towards motherhood, to its monthly visit, and finally its disappearance, synonymous with the end of both their fertility and their sexuality. This female periodicity was the point of view from which they saw the afflictions of their husbands' bodies. But the effects of their point of view were obvious: sending a warning signal about the men's libido and sexuality. It should be noted that, once again, women and doctors were in perfect agreement, because the earliest treatises devoted to andropause founded the reality of that state on the disappearance of sexual function.

\section{For whom the bell tolls}

By "inventing" first menopause, then andropause, doctors could be thought to have imposed a death sentence on both men's and women's sex lives. But that probably wasn't very hard to do, since it coincided so neatly with long-established habits. To put it another way, couples had been practicing sexual abstinence in the autumn of their lives long before doctors began advising it. The Pierre Rivière parricide is well known in France. The long text he wrote to explain his act has been widely commented on. One interesting detail that didn't get much attention, however, was that in order to shield herself from her husband's assaults, Pierre's mother had her two younger 
children, Jules and Victoire, sleep in the marital bed. ${ }^{13}$ The couple fought constantly, and often violently. Yet it hardly seems necessary to arrive at such a state of marital disenchantment in order to cease carnal relations. Thus, in the late $19^{\text {th }}$ century, an observer in the area of Toulouse condemned, in no uncertain terms, men's tendency to "put away their tools," much too early in his opinion, and for no good marital or emotional reason. ${ }^{14}$ By the same token, the women I interviewed made it clear that, as they reached menopause, they had imposed sexual abstinence on their spouses. They used colorful but clear expressions to let me know. They had "put up a fence in their bed" (literally: "put a wooden shoe in the bed") or had "sent him to see the woman next door." Some of those who had not managed to impose abstinence on their husbands had ben terrified when their periods first disappeared, dreading that the absence announced the arrival of the 'baby of the family', who would be far younger than his or her siblings. The possibility of such a late birth was unanimously seen as scandalous, even as something to be ashamed of! And what they had feared for themselves, they criticized roundly in other women, referring in damning terms to women who had given birth after their own daughters were old enough to procreate - or even worse - were already married and had one or more children of their own. So-and-so had announced her pregnancy on the day of her youngest daughter's wedding! Someone else had had a baby when her oldest son was nearly 20! And a third had been in the hospital at the same time as her own daughter - and they were both there for the same reason: to give birth! The women systematically stigmatized families in which the order of the generations had been overturned, and the nephew was older than the uncle. They weren't surprised when families with jumbled generations had problems (sterility, suicide, unmarried children, "deviant" sexuality, etc.). They were all perfectly logical consequences, in their book, of the unspeakable behavior of those "wayward mothers." The fact was that those

13 In 1835, Pierre Rivière killed his mother, sister and brother. In France, the confession he wrote in jail has been published, extensively studied, notably by Michel Foucault, and made into a film. Rivière 1973: 135-136.

14 Lavigne 1875: 372-373. 
women, at once recent mothers and young grandmothers, were breaking a taboo that may not have been clearly written, yet which governed couples' sex lives nevertheless, as the historiandemographer Jean-Claude Sangoï has shown. ${ }^{15}$ Mothers should cease to be fertile - or at least shouldn't be flaunting manifest signs of fertility - when their children have reached the age to become parents themselves. They should embrace the role of "grandmother" fully. Two generations of the same family couldn't and shouldn't be indulging in fertility the same time. In a nutshell, Little Red Riding Hood should eat her grandmother, as Yvonne Verdier has explained with different words and in a different context. ${ }^{16}$ And what more efficient way to avoid these untimely, "shameful" births than to cease all sexual relations? "A fence in bed" having limited effectiveness, it's easy to see how the women I interviewed were relieved by their hysterectomies. Thus, both menopause and andropause, which are founded on a pathologization of bodies that leads to the death of sexuality, turn out, upon analysis, to be the direct descendants of extremely old social taboos that they have both medicalized and legitimized.

\section{Sexuality under surveillance}

But that's so outdated, you might say. The women I interviewed were "little old ladies from the country" who perpetuated behaviors that in other places - particularly urban centers - and social milieus had disappeared or were at least evolving. Besides, 20 years have passed since I started my research, and things have changed profoundly in that time. People in their 50s and 60s are no longer seen as elderly. While they may not have said, like the singer Tino Rossi, that "life begins at 60," couples assure us that they are still enjoying a satisfying lifestyle, and insist that their sex lives carry on into old age. By 2012,

15 Research carried out by Jean-Claude Sangoï and one of his female students, Nadège Fabre, into the Bas-Quercy and Val d'Aran regions of the Pyrenees in the $19^{\text {th }}$ century, showed that women of reproductive age whose daughters are married were considerably less fertile than those whose daughters were still single. See Fine, Moulinié \& Sangoï 2009 and Fabre 2003 and 2004.

16 Verdier 1978 and 1980. 
we've come a long way since those dark and painful hours that doctors described and the women I interviewed had lived through! Should we then believe that the barrage, whose patient construction over more than a century I had studied, has suddenly given way? I wouldn't count on it. While the discourse about bodies of advancing years is evolving, 50- and 60-somethings' sex lives still isn't accepted as well as people think.

It is true that "having it all taken out" is no longer popular amongst women in their 50s today. Instead of seeing it as a relief, it is now considered to be an unacceptable mutilation. Nowadays, women prefer hormone replacement therapy to the scalpel. But going on "HRT" isn't like drinking herbal tea! ${ }^{17}$ While the latter is a strictly personal decision (no prescription necessary), the former is firmly in the hands of the medical profession, which evaluates the necessity, determines the dosage, writes the prescription and keeps track of the effects through regular check-ups. Particularly since the publication in the early 2000s of two studies focusing on the side effects of these treatments on certain specifically female organs, ${ }^{18}$ women have been particularly motivated to get proper medical supervision. Furthered by doubt and anxiety, medicalization has in fact grown and spread, sticking to the trajectory that started 200 years ago. Nothing new, in sum, as far as women go. The same cannot be said about men, however

In 1975, the French writer Romain Gary published a novel with a singular title, to say the least: Au-delà de cette limite, votre ticket n'est plus valable ("Beyond this Point) Your Ticket Is No Longer Valid"). It recounts the love story between Jacques Rainier, 59, and Laura, a beautiful Brazilian woman who is 30 years younger. It also describes the physical difficulties the almost 60-year-old man encounters in this passionate affair. Difficulties that upset him so much that he considers

17 I am thinking, to name just one example, of the Ménophytéa herbal-tea range with its explicit name - which had an absolutely spectacular ad campaign on French radio in the spring of 2012.

18 The results of two epidemiological studies, the Women's Health Initiative (WHI) in the USA and the Million Women Study in the U.K., were published in 2002 and 2003, respectively. They drew attention to the risks related to hormonal replacement therapy, including strokes, and breast and uterine cancer. 
committing a kind of suicide by proxy so as not to have to confront what feels to him like a disaster: not only is his sex life going down the drain, but to his mind, his whole life is going down with it. Seventeen years later, Georges Debled, a urologist whose name is closely associated to andropause, ${ }^{19}$ published a book too. The title is clearly modeled on Gary's, although it contradicts the former directly: Au-delà de cette limite, votre ticket est toujours valable, ("Beyond this Point) Your Ticket Is Still V alid"). And just in case anyone doesn't get the allusion, the subtitle is Comment vaincre le vieillissement de l'homme? ("How Can We Conquer Male Aging") 20 The point seems to be that, as far as Debled is concerned, Jacques Rainier's anguish and distress at the decline of his virility are baseless, a pure novelistic invention. Except that a quick glance at the table of contents of Debled's book would be enough to unsettle the most swaggering but graying Don Juan. Won't he find that, "Andropause concerns all men over 40" and that "Eunuchs are a model for andropause"21? Doesn't the book address "Erectile Dysfunction," "Prostate Problems," "Wrinkled Skin," "Anemia," "Shortness of Breath," "Renal Insufficiency," "Arteriosclerosis," "Angina pectoris and Cardiac Infarction"? The novel and the urologist's book unanimously assert that, "beyond a certain age," sexuality declines. But the similarities stop there. Romain Gary's novel features a hero whose love affair escaped medical attention, because Jacques Rainier soon turns from the amused gaze of the doctor he consults early in the tale. Georges Debled, on the other hand, believes that although an active love life is still both possible and desirable, it can only exist under strict medical supervision. By 2012, it must be admitted, Gary has definitively lost, and Debled has won. How else could it be?

When it comes to keeping a watchful eye on male bodies, women's attention has never waned. While back in the 1980s and 1990 s, they did it almost clandestinely, things are quite different now.

19 He wrote a book that was published in 1988 whose title speaks for itself: L'andropause : causes conséquences et remèdes.

20 Debled 1992.

21 One can read in its pages: "Post-andropausal men look like eunuchs who were castrated after puberty. Many of them go bald.” (Debled 1992: 33). 
That role has practically been officially attributed to them. But by whom? To find the answer, go to a newspaper stand. Men's magazines don't talk about men's health very much, to put it mildly. Often quite specialized, they would rather talk about eroticism, sports, mechanics or DIY. Anything but medicine! To learn about that, you have to go to health magazines for the general public (i.e. not doctors) such as, in France, Top Santé; or to women's magazines (Femme Actuelle and Maxi, among others). And both of those kinds of magazines are bought almost exclusively by women. In the same way, while radio and television programs (particularly Magazine de la santé on France 5) have no qualms about discussing andropause, they are aimed at an almost exclusively female audience. ${ }^{22}$ Their outlook is determinedly upbeat. They endlessly repeat the injunction, but in a cheerful, we're-old-friends tone of voice, that it's out of the question to give up on sex in your 50s, and that it's still perfectly possible for a couple to have a satisfying sex life after that milestone. On one condition: you must "keep an eye on your health." That is the keystone to the whole system. Among the many roles that Femme Actuelle and suchlike assign to women is guardian of the whole family's health, including, in fact particularly, their husband's, as he is presented as being either too careless or too unaware of these crucial issues, too reserved or too proud to raise the topic. In any case, it's up to them to "take care of their man," which includes convincing him, as diplomatically as necessary, to go for regular check-ups, especially when he is approaching his $50 \mathrm{~s}$ or $60 \mathrm{~s}$. This constant medical supervision, this subjection of the virile body to the medical gaze, is the price to pay in order for the couple's sex life to continue to exist. In a nutshell, through these media mouthpieces aimed essentially at women but very concerned with the health of "mature men," doctors have delegated the responsibility for medical supervision to wives.

Are men resisting this "medical-media-matrimonial" pressure? Seems unlikely. Granted, not many are likely to admit they're going through andropause. But even fewer of them dare argue when their spouse says she's worried about some ailment or other and that they

22 For more about the role of women's magazines, see Moulinié 2004. 
should "make an appointment to see the doctor." At most, they may try to put it off, to delay subjecting themselves to the doctor's gaze. But they all know that they're going to have to "bite the bullet." Nowadays, as in the past, they know perfectly well what concerns are lurking behind the check-ups. They know it's about their virility. Not without a certain skepticism, which the men themselves share. If there was any doubt about that, listening to men's jokes will put paid to it. Putting it crudely, if you analyze "dirty jokes," you'll see that, far from denying it, they focus on the gradual, progressive disappearance of the sex drive with age. Let's look at a sampling of them. The first one features an elderly couple. After years of sexual indifference, they're suddenly frolicking like newlyweds in a field. Monsieur's newfound enthusiasm surprises and thrills Madame, who thinks he's discovered the fountain of youth. But, as he is forced to admit, that's not it at all: it's because he's sitting on an electrified fence. In another one, two old men are sitting on a park bench. One of them is boasting about how his strength has miraculously decupled with age. The proof: when he was younger, he couldn't "bend" his member, and now he can do it just like that! As for Viagra, whose very existence on the market is significant, it has been an inexhaustible source of inspiration for jokes and puns on chemistry's capacity to more or less replenish 50-somethings' flagging sex drive. The fact is, men's own humor acknowledges the failings of their bodies loud and clear. And when all is said and done, they have discreetly but completely surrendered, accepting their wives' and doctors' verdict: in order to maintain a love life, men have to "keep an eye on things," and, even more importantly, let doctors "keep an eye on things" for them.

Since Ancient Greece, but with increasing speed since the $18^{\text {th }}$ century, medicine has been controlling the female body, leaving its mark on it. All the talk, first of "menopause" and then of "andropause", is just one among many elements of proof of this. Nevertheless, these expressions also invite us to qualify that comment. This loss of control wasn't pulled off against women's will, nor even, more simply, without them. On the contrary, they were powerful and efficient relays for the message. They participated in it rather than being subjected to it. For that matter, they weren't alone. Men haven't escaped it either, caught between their spouses and their 
doctors. Although the techniques that would today be considered cruel and unnecessary, like hysterectomies, are disappearing, medical supervision, far from fading, is being reinforced instead. And actually, while the sex life of people in their sixties is no longer considered problematic, as long as it is framed, fettered and supervised by Medicine, the sexuality of the "very old" is simply not supposed to exist. For instance, in 1992, a multidisciplinary team made up of epidemiologists, demographers, psychologists, psychiatrists, sociologists and economists, among others, launched the large-scale Analyse des Comportements Sexuels en France ("Analysis of Sexual Behaviors in France"), which is generally referred to nowadays as the "ACSF Study". The population studied was divided into age groups. The oldest one was "60-69 years old." 23 Message received, loud and clear! The norm has been established. The cut-off date is still there. It just falls a little later than in the past.

\section{Translated by Regan Kramer}

\section{Bibliography}

DeBLeD Georges, 1988, L'andropause : causes, conséquences et remèdes, Paris, Maloine.

—, 1992, Au-delà de cette limite, votre ticket est toujours valable, Paris, Albin Michel.

DELANOË Daniel, 1997, «Les représentations de la ménopause : un enjeu des rapports sociaux d'âge et de sexe », Contraception, Fertilité, Sexualité, 25, 11, p. 853-860.

_, 2001, «La ménopause comme phénomène culturel », Champ psychosomatique, 24, p. $57-67$.

Delbes Christiane \& Joëlle GAYmu, 1997, «L'automne de la vie. La vie sexuelle après 50 ans ", Population, 6, p. 1439-1484.

Diasio Nicoletta, 2002, «L'inverno delle donne. La costruzione del concetto di menopausa tra scienza e metafisica», in Antonio GUERCI \& Stefania Consigliere (eds.), Il Vecchio allo specchio. Percezioni e rappresentazioni della vecchiaia, Genova, Erga edizioni, p. 310-325.

Diasio Nicoletta \& Virginie VINEL, 2010, «Temps et passages de la vie féminine : l'exemple de la ménopause », in Louise Hamelin-Brabant, Louise Bujol \&

23 Delbès \& Gaymu 1997. 
Nicolas Vonarx (eds.), Des sciences sociales dans le champ de la santé et des soins infirmiers. À la rencontre des âges de la vie, des vulnérabilités et des environnements, Québec, Presses de l'Université Laval, p. 59-80.

Diasio Nicoletta \& Virginie Vinel (dir.), 2007, Il Tempo incerto. Antropologia della menopausa, Milan, Franco Angeli.

FABRE Nadège, 2003, «Étude démographique en pays cordais de 1793 à 1913 », Université de Toulouse-le Mirail, master's thesis supervised by Jean-Claude Sangoï.

—, 2004, «Fécondité et sexualité des femmes dans le Sud-Ouest de la France au XIXe siècle ", Paris, EHESS, DEA [short dissertation] supervised by Agnès Fine \& Jean-Claude Sangoï.

Fine Agnès, MouliniÉ Véronique \& Jean-Claude SANGOÏ, 2009, « De mère en fille. La transmission du pouvoir génésique », L’homme, 191, p. 37-76.

GARY Romain, 1975, Au-delà de cette limite, votre ticket n'est plus valable, Paris, Gallimard.

HÉritier-Augé Françoise, 1998, "Anthropologie de la ménopause », in Claude Sureau, Françoise Héritier-Augé, Sylvie Epelboin, Daniel Delanoë \& Sylvain Simoun (eds.), Stéroïdes, ménopause et approche socio-culturelle, Paris, Elsevier, p. 11-21.

LAvigne Bertrand, 1875, Histoire de Blagnac: sa baronnie, ses barons, ses châteaux, son prieuré, ses églises, Toulouse, L. Capdeville.

MOULINIÉ Véronique, 1998, La cbirurgie des âges. Corps, sexualité et représentations du sang, Paris, Éditions de la Maison des sciences de l'homme.

—, 2000, "Corps d'hommes, mots de femmes ", in Monique Membrado \& Annick RIEU (dir.), Sexes, espaces et corps. De la catégorisation du genre, Toulouse, Éditions Universitaires du Sud, p. 207-221.

—, 2004, «De l'âge critique à l'andropause : réflexions sur la 'validité du ticket'», in Noël BARBE \& Emmanuelle JALLON (dir.), Vous avez dit «Ages de la vie »?, Vesoul, Conseil général de la Haute-Saône, coll. «Texte (Pluriel)», p. 134-171.

RIVIÈRE Pierre, 1973, Moi, Pierre Rivière ayant égorgé ma mère, ma sceur et mon frère... Un cas de parricide au XIXe siècle, présenté par Michel Foucault, Paris, Gallimard-Juillard.

PAuchet Victor, 1932, L'automne de la vie. L'bomme et la femme à l'âge critique, Paris, Éditions J. Oliven.

Scull Andrew \& Diane Favreau, 1987, «Médecine de la folie ou folie des médecins ? Controverse à propos de la chirurgie sexuelle au $19^{\mathrm{e}}$ siècle ", Actes de la Recherche en Sciences Sociales, 68, p. 31-44.

TiLLIER Annick, 2005, «Un âge critique. La ménopause sous le regard des médecins des XVIII' et XIXe siècles », Clio. Histoire, femmes et sociétés, 21, p. 269-280. 
Verdier Yvonne, 1978, «Grands mères, si vous saviez... Le Petit Chaperon rouge dans la tradition orale », Cahier de littérature orale, 4, p. 17-55.

—, 1980, «Le Petit Chaperon rouge dans la tradition orale », Le Débat, 3, p. 31-61.

VINEL Virginie, 2002, «Les représentations de la ménopause dans des documents français contemporains ", in Antonio GuERCI \& Stefania Consigliere (a cura di), Il Vecchio allo specchio : percezioni e rappresintazioni della vecchiaia, Genova, Erga edizioni, p. 326-337.

—, 2004a, "La ménopause : instabilité des affects et des pratiques en France », in Françoise Héritier \& Margarita Xanthakou (eds.), Corps et affects, Paris, Odile Jacob, p. 221-236.

—, 2004b, "Ménopause et andropause à la lumière du 'dispositif de sexualité' », Le Portique (en ligne), 13/14 (http://leportique.revues.org/index628.html).

—, 2005, «Présentation des recherches sur ménopause et andropause dans la France contemporaine », Le Portique (online), Archives des Carnets du Genre, Carnet 1, (http://leportique.revues.org/index712.html)

-, (ed.), 2007, Féminin, masculin: anthropologie des catégories et des pratiques médicales, Strasbourg, Éditions du Portique, coll. «Les cahiers du Portique », 4.

—, 2008, «Pluralisme thérapeutique de femmes françaises en période de ménopause », Revue Internationale du Médicament, 2/1, p. 96-138

(http://chaine.uqam.ca/revue RIM/RIM2/PDF/RIM2-4-Vinel96-138.pdf). 